\title{
Integration of Seismic Refraction and 2D Electrical Resistivity in Locating Geological Contact
}

\author{
Nisa’ Ali, Rosli Saad, M. M. Nordiana \\ Geophysics Section, School of Physics, Universiti Sains Malaysia, Penang, Malaysia \\ Email: nisa_ali_89@yahoo.com
}

Received 2013

\begin{abstract}
The aim of this research is to locate the geological contact for engineering purpose applying seismic refraction and 2D electrical resistivity method. Resistivity and seismic refraction method was conducted on four survey lines with 3 lines running from NW to SE which about parallel to each other and $40 \mathrm{~m}$ apart while the fourth line was running from SW to NE. The 2D resistivity survey used minimum electrode spacing of $5 \mathrm{~m}$ and the survey used pole-dipole array with minimum current was $2 \mathrm{~mA}$ and maximum was $20 \mathrm{~mA}$. The seismic refraction survey used $5 \mathrm{~m}$ geophone spacing with offset shot was $+30 \mathrm{~m}$ and $-30 \mathrm{~m}$. Resistivity results generally show the area was divided into two main zones, alluvium with resistivity value of $10-800 \mathrm{ohm}-\mathrm{m}$, and granite bedrock with resistivity value of $>2500 \mathrm{ohm}-\mathrm{m}$. There is a geological contact between granite and alluvium. The seismic results show the area consists of two layers. The first layer (top layer) with velocity of 460 - $900 \mathrm{~m} / \mathrm{s}$ which was alluvium mixed with boulders. The second layer with velocity of $2060-3140 \mathrm{~m} / \mathrm{s}$ with depth 71 - 90 MSL. The thickness of the overburden is $5-15 \mathrm{~m}$.
\end{abstract}

Keywords: Geological Contact; 2D Electrical Resistivity; Seismic Refraction

\section{Introduction}

A geological contact is a boundary between two units that is identified on the basis of a compositional, textural, structural, or temporal difference between units [1]. The ways in which rock bodies fit together are deduced from geologic mapping, supplemented wherever possible by drilling and geophysical data [2].

The 2D electrical resistivity method is most suitable for interpreting geological structures in subsurface while seismic method is valuable for mapping depth of bedrock and fracture zones but fail to indicate the depth or dip direction of the zone as 2D resistivity method could [3]. Thus, integration of seismic refraction and 2D electrical resistivity method will give useful and better information on delineating contact and faults for engineering purpose.

The refraction seismic method depends on seismic ray paths being bent at velocity discontinuities. A compressional wave that impinges on a boundary separating two media with different acoustic impedances is partially reflected and partially refracted into the lower medium [4]. Measurements of travel-time as a function of range can be transformed into a graph of velocity as a function of depth. Velocity boundaries usually coincide with geological boundaries and a cross-section on which velocity interfaces are plotted may therefore resemble the geological cross-section, although the two are not necessarily the same [5]. Figure 1 shows seismic wave velocities in earth materials.

Resistivity methods are used in engineering geological investigations of sites prior to construction [6]. The resistivity measurements are normally made by injecting current into the ground through two current electrodes and measuring the resulting voltage difference at two potential electrodes [7]. Resistivity surveys give a picture of the subsurface resistivity distribution. The spatial contact between rocks will be identified based on the variation of resistivity values. The distribution of the resistivity of the earth material will be used to interpret the geology of the subsurface based on the resistivity value for common geologic materials (Table 1).

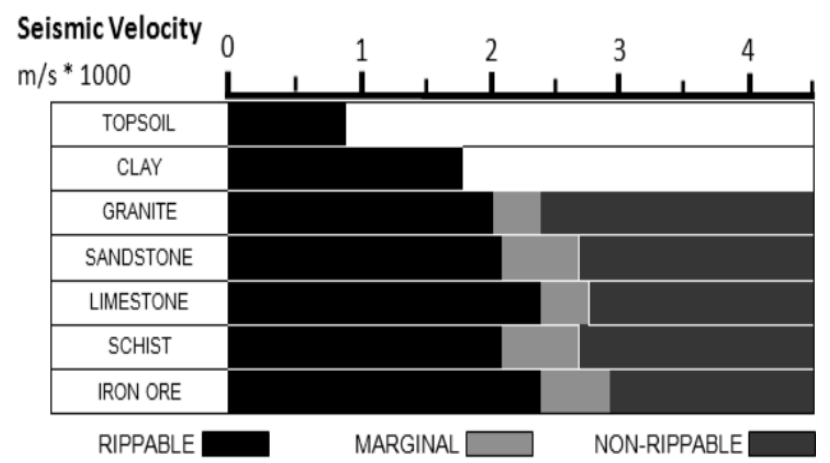

Figure 1. Seismic $\mathbf{P}$-wave velocities in earth materials. 


\section{Survey Area}

The study area is located at PT 8088, Mukim Batu, Gombak, Selangor, Malaysia with the coordinate of $3^{\circ}$ $15^{\prime} 37.2^{\prime \prime} \mathrm{N}$ and $101^{\circ} 38^{\prime} 48.22^{\prime \prime} \mathrm{E}$. The area was cut and filled with undulating surface and some bushes [9] with fine grained granite comprising granite porphyry and microgranite as the main rock material [10].

\section{Methodology}

In this survey, two geophysical survey has been carried out which are 2D resistivity method and seismic refraction survey.

Four resistivity lines were set with three lines (SELA1SELA3) were about $40 \mathrm{~m}$ apart and parallel to each other while the other one (SELA4) was set up crossing the three lines (Figure 2). Included in Figure 2 are the locations of the boreholes (BH3 \& BH5). BH3 situated 14.5 $\mathrm{m}$ from SELA2 and $37.5 \mathrm{~m}$ from SELA4. BH5 located $8.0 \mathrm{~m}$ from SELA2 and $17.0 \mathrm{~m}$ from SELA4. This research was carried out by plant in the electrodes into the ground in a straight line with a constant spacing of $5 \mathrm{~m}$. A multi electrode selector will be used to select the active electrodes for each measurement. The value was collected by the resistivity meter, which is ABEM SAS4000 system using pole-dipole array with minimum current of $2 \mathrm{~mA}$ and maximum was $20 \mathrm{~mA}$. The values of resistivity obtained from each measurement are plotted on a pseudo-section and contoured.

Four seismic spread was set up in line with resistivity method, SELA1 - SELA4 (Table 2). The length of each seismic spread is $115 \mathrm{~m}$ with offset shot $+30 \mathrm{~m}$ and $-30 \mathrm{~m}$.

Table 1. Resistivity of common geologic materials [8].

\begin{tabular}{lc}
\hline \multicolumn{1}{c}{ Material } & Resistivity $(\Omega \mathrm{m})$ \\
\hline Granite & $300-1000000$ \\
Sandstones & $1-\left(7.4 \times 10^{8}\right)$ \\
Alluvium and sand & $10-800$ \\
Clays & $1-100$ \\
\hline
\end{tabular}

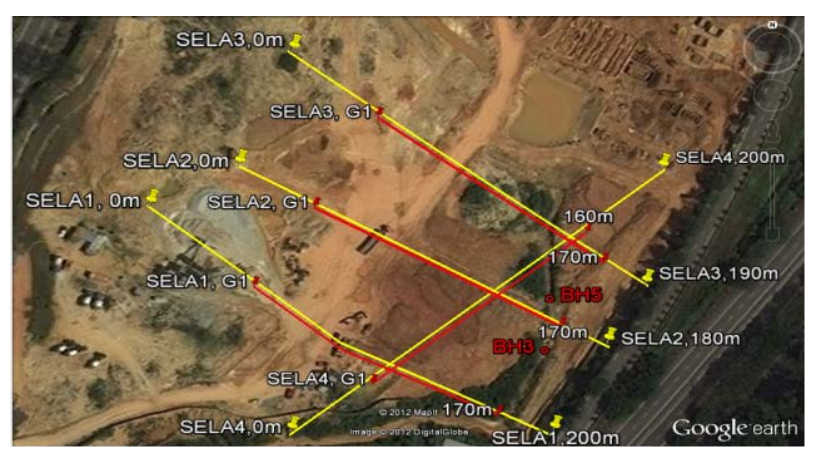

Figure 2. The survey area with survey lines and boreholes.
Table 2. Distance and position of resistivity and seismic survey lines.

\begin{tabular}{lcc}
\hline & Resistivity & Seismic spread (refer to resistivity line) \\
\hline SELA1 & $0-200 \mathrm{~m}$ & $55-170 \mathrm{~m}$ \\
SELA2 & $0-180 \mathrm{~m}$ & $55-170 \mathrm{~m}$ \\
SELA3 & $0-190 \mathrm{~m}$ & $55-170 \mathrm{~m}$ \\
SELA4 & $0-200 \mathrm{~m}$ & $45-160 \mathrm{~m}$ \\
\hline
\end{tabular}

The study was conducted by utilizing a $16 \mathrm{lb}$ sledgehammer as source of wave, 24 units of $24 \mathrm{~Hz}$ geophones and ABEM MK6 seismograph. The survey line uses $5 \mathrm{~m}$ geophones spacing and 7 shot points for each spread.

\section{Results and Discussion}

The results obtain from seismic refraction and 2D resistivity is supported by borehole records. Seismic cross sections have provided the depth profile of the survey area while the resistivity pseudosections gave the resistivity value of the subsurface.

\subsection{Seismic Refraction}

The results from the seismic cross sections (Figures 3-6), show that the survey area consists of two layers. The seismic velocities for the first layer range from $460 \mathrm{~m} / \mathrm{s}$ to $900 \mathrm{~m} / \mathrm{s}$ and consist of alluvium mix with boulders. The second layer velocities range from $2060 \mathrm{~m} / \mathrm{s}$ to 3140 $\mathrm{m} / \mathrm{s}$ with depth 71 - 90 MSL. The thickness of the first layer is $5-15 \mathrm{~m}$. Based on these results, the second layer abrupt velocity change has outlined the geological contact between the top layer and the bedrock.

\subsection{D Resistivity}

Resistivity results (Figures 7-10) are pseudo-sections showing the resistivity value of the subsurface with the red line is the second layer of the seismic refraction result. Generally, the area was divided into two main zones, alluvium with resistivity value of $10-800 \Omega \mathrm{m}$, and granite bedrock with resistivity value of $>2500 \Omega \mathrm{m}$. There is a contact zone between granite and alluvium which produces faults.

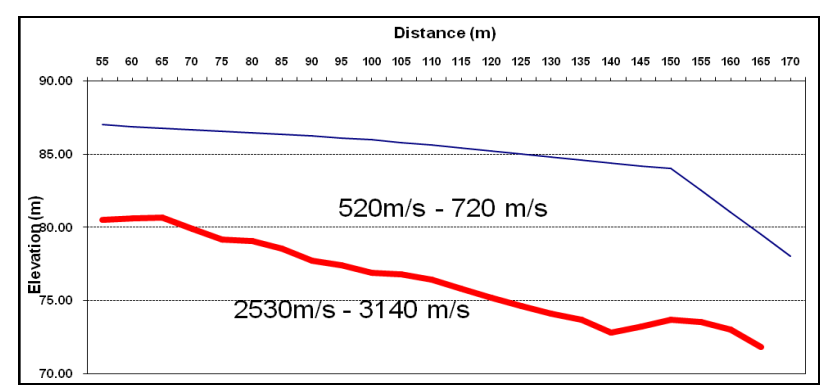

Figure 3. Seismic cross-section of SELA1. 


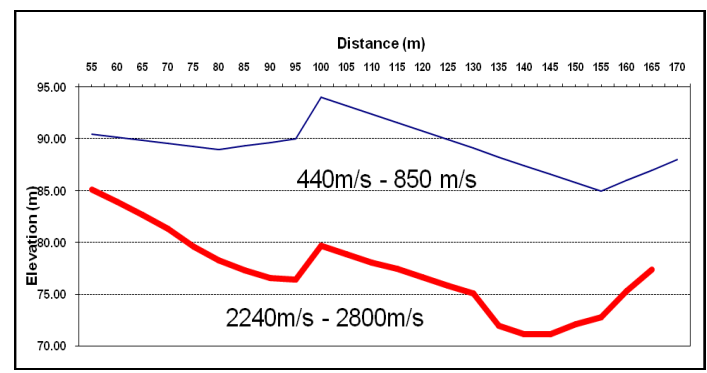

Figure 4. Seismic cross-section of SELA2.

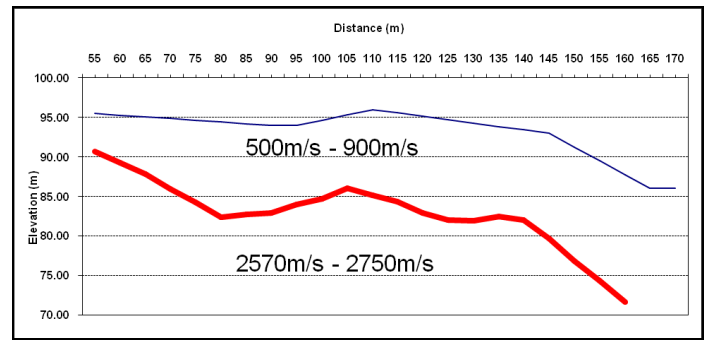

Figure 5. Seismic cross-section of SELA3.

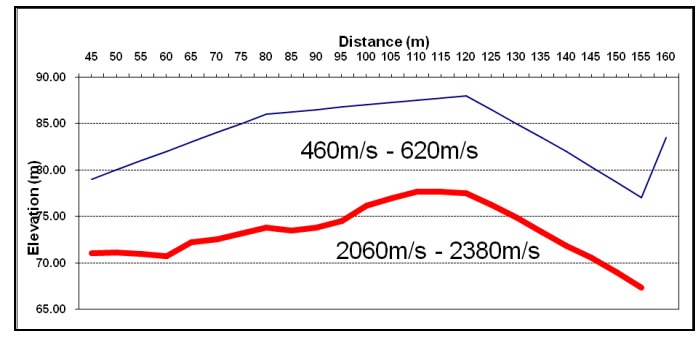

Figure 6. Seismic cross-section of SELA4.

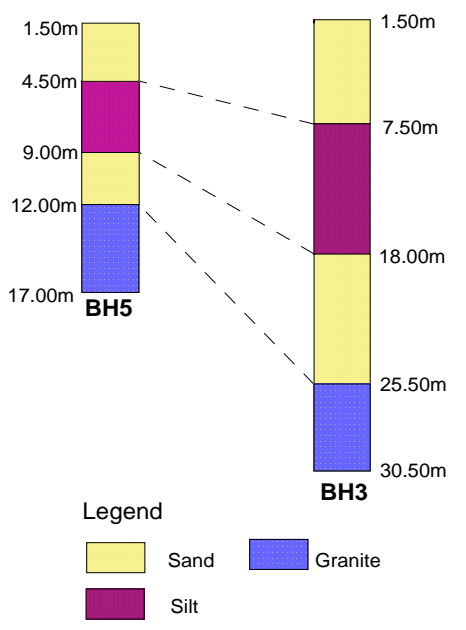

Figure 7. Cross section of borehole data BH3 and BH5.

\subsection{Borehole Records}

Borehole data, BH5 (Table 3) and BH3 (Table 4) show that the study area is covered by alluvium, mostly sand. Granite is found at depth of $12.0 \mathrm{~m}$ and this fit with the resistivity value pseudo-section of SELA2 (Figure 8) which indicates granite near $\mathrm{BH} 5$ area.

Table 4 providing bore $\log$ for BH3. Similar to the previous borehole, the subsurface materials for this borehole are alluvium and granite. BH3 has granite as bedrock at depth of $25.5 \mathrm{~m}$.

Figure 11 shows the cross section of borehole data. From the cross section, the bore log has the same lithology though the thicknesses are vary.

Table 3. Borehole data, BH5.

\begin{tabular}{|c|c|c|c|c|c|c|c|c|c|}
\hline \multirow{2}{*}{ Depth (m) } & \multirow{2}{*}{ Description } & \multicolumn{6}{|c|}{$\mathrm{SPT}^{\mathrm{a}}$} & \multirow{2}{*}{$\mathrm{N}$} & \multirow{2}{*}{$\begin{array}{l}\text { Rec. }^{b} \\
\text { ratio }\end{array}$} \\
\hline & & $75 \mathrm{~mm}$ & $75 \mathrm{~mm}$ & $75 \mathrm{~mm}$ & $75 \mathrm{~mm}$ & $75 \mathrm{~mm}$ & $75 \mathrm{~mm}$ & & \\
\hline $\begin{array}{l}1.50 \\
1.95\end{array}$ & $\begin{array}{l}\text { Medium dense, medium brown moltled grey silty fine SAND with } \\
\text { little gravel }\end{array}$ & 2 & 4 & 3 & 3 & 3 & 3 & 12 & $53 \%$ \\
\hline $\begin{array}{l}3.00 \\
3.45\end{array}$ & 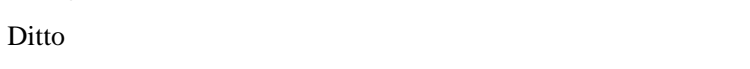 & 3 & 4 & 4 & 9 & 6 & 5 & 24 & $61 \%$ \\
\hline $\begin{array}{l}4.50 \\
4.95\end{array}$ & Stiff, medium brownish grey sandy SILT with a little gravel & 2 & 4 & 3 & 2 & 2 & 2 & 9 & $44 \%$ \\
\hline $\begin{array}{l}6.00 \\
6.45\end{array}$ & Ditto & 2 & 2 & 3 & 4 & 2 & 3 & 12 & $51 \%$ \\
\hline $\begin{array}{l}7.50 \\
7.95\end{array}$ & Ditto & 4 & 3 & 4 & 3 & 2 & 2 & 11 & $55 \%$ \\
\hline $\begin{array}{l}9.00 \\
9.45\end{array}$ & Medium dense, light to medium brownish grey silty SAND & 5 & 9 & 9 & 7 & 7 & 6 & 29 & $38 \%$ \\
\hline $\begin{array}{l}10.50 \\
10.95\end{array}$ & Dense to very dense, light to medium brownish grey silty SAND & 5 & 7 & 9 & 8 & 8 & 9 & 34 & $36 \%$ \\
\hline 12.00 & $\begin{array}{l}\text { Pale to light grey moltled dark grey, moderately fractured, } \\
\text { moderately weathered, medium to strong coarse grain GRANITE }\end{array}$ & \multicolumn{8}{|c|}{$\mathrm{CR}^{\mathrm{c}}=1.50 \mathrm{~m} ; \mathrm{CRR}^{\mathrm{d}}=0.92 \mathrm{~m} / 1.50 \mathrm{~m} ; \mathrm{RQD}^{\mathrm{e}}=35 \%$} \\
\hline 13.50 & Ditto & \multicolumn{8}{|c|}{$\mathrm{CR}=1.50 \mathrm{~m} ; \mathrm{CRR}=0.82 \mathrm{~m} / 1.50 \mathrm{~m} ; \mathrm{RQD}=37 \%$} \\
\hline 15.00 & $\begin{array}{l}\text { Pale to light grey mottled dark grey, highly fractured, moderately } \\
\text { weathered medium to strong coarse grain GRANITE }\end{array}$ & \multicolumn{8}{|c|}{$\mathrm{CR}=1.50 \mathrm{~m} ; \mathrm{CRR}=0.80 \mathrm{~m} / 1.50 \mathrm{~m} ; \mathrm{RQD}=8 \%$} \\
\hline $\begin{array}{l}16.50 \\
17.00\end{array}$ & Ditto & \multicolumn{8}{|c|}{$\mathrm{CR}=0.50 \mathrm{~m} ; \mathrm{CRR}=0.20 \mathrm{~m} / 0.50 \mathrm{~m} ; \mathrm{RQD}=\mathrm{NIL}$} \\
\hline End of $\mathrm{BH}$ & 15 at depth 17.00 m.b.g. ${ }^{f}$ & & & & & & & & \\
\hline
\end{tabular}

a. Standard Penetration Test; b. Recovery c. Coring Run; d. Core Recovery; e. Rock Quality Designation; f. Meters Below Ground Level. 
Table 4. Borehole data, BH3.

\begin{tabular}{|c|c|c|c|c|c|c|c|c|c|}
\hline \multirow{2}{*}{$\begin{array}{l}\text { Depth } \\
(\mathrm{m})\end{array}$} & \multirow{2}{*}{ Description } & \multicolumn{6}{|c|}{ SPT } & \multirow{2}{*}{$\mathrm{N}$} & \multirow{2}{*}{$\begin{array}{l}\text { Rec. } \\
\text { ratio }\end{array}$} \\
\hline & & $75 \mathrm{~mm}$ & $75 \mathrm{~mm}$ & $75 \mathrm{~mm}$ & 75 mm & $75 \mathrm{~mm}$ & $75 \mathrm{~mm}$ & & \\
\hline $\begin{array}{l}1.50 \\
1.95\end{array}$ & $\begin{array}{l}\text { Loose, light grey silty medium SAND with some } \\
\text { gravel }\end{array}$ & 2 & 1 & 2 & 2 & 2 & 1 & 7 & $27 \%$ \\
\hline $\begin{array}{l}3.00 \\
3.45\end{array}$ & $\begin{array}{l}\text { Medium dense, light grey medium brown silty medium } \\
\text { SAND with some gravel }\end{array}$ & 2 & 3 & 3 & 3 & 6 & 4 & 16 & $47 \%$ \\
\hline $\begin{array}{l}4.50 \\
4.95\end{array}$ & Loose, light grey striped light brown silty fine SAND & 1 & 0 & 1 & 1 & 1 & 2 & 5 & $53 \%$ \\
\hline $\begin{array}{l}6.00 \\
6.45\end{array}$ & $\begin{array}{l}\text { Very loose, light grey striped light brown silty fine } \\
\text { SAND }\end{array}$ & 1 & 1 & 1 & 0 & 0 & 1 & 2 & $60 \%$ \\
\hline $\begin{array}{l}7.50 \\
7.95\end{array}$ & $\begin{array}{l}\text { Soft to medium stiff, light grayish brown sandy SILT } \\
\text { with some gravel }\end{array}$ & 1 & 0 & 0 & 1 & 2 & 1 & 4 & $67 \%$ \\
\hline $\begin{array}{l}9.00 \\
9.45\end{array}$ & $\begin{array}{l}\text { Medium stiff, light grayish brown sandy SILT with } \\
\text { some gravel }\end{array}$ & 1 & 0 & 1 & 1 & 2 & 2 & 6 & $64 \%$ \\
\hline $\begin{array}{l}12.00 \\
12.45\end{array}$ & Ditto & 2 & 3 & 2 & 1 & 3 & 2 & 8 & $60 \%$ \\
\hline $\begin{array}{l}13.50 \\
13.95\end{array}$ & Stiff, light to medium grey sandy SILT & 2 & 3 & 4 & 2 & 2 & 2 & 10 & $53 \%$ \\
\hline $\begin{array}{l}15.00 \\
15.45\end{array}$ & Ditto & 3 & 3 & 4 & 3 & 3 & 4 & 14 & $67 \%$ \\
\hline $\begin{array}{l}16.50 \\
16.95\end{array}$ & $\begin{array}{l}\text { Stiff, medium grayish brown sandy SILT with traces } \\
\text { of gravel }\end{array}$ & 2 & 4 & 4 & 3 & 2 & 3 & 12 & $71 \%$ \\
\hline $\begin{array}{l}18.00 \\
18.45\end{array}$ & Loose, medium grayish brown silty fine SAND & 2 & 1 & 2 & 3 & 2 & 2 & 9 & $76 \%$ \\
\hline $\begin{array}{l}19.50 \\
19.95\end{array}$ & Medium dense, light brown light grey silty fine SAND & 3 & 3 & 4 & 3 & 5 & 2 & 14 & $71 \%$ \\
\hline $\begin{array}{l}21.00 \\
21.45\end{array}$ & Medium dense, light brown light grey silty fine SAND & 4 & 7 & 6 & 7 & 7 & 5 & 25 & $51 \%$ \\
\hline $\begin{array}{l}22.50 \\
22.95\end{array}$ & $\begin{array}{l}\text { Medium dense, light to medium brownish grey } \\
\text { silty fine SAND }\end{array}$ & 9 & 7 & 7 & 8 & 7 & 6 & 28 & $44 \%$ \\
\hline $\begin{array}{l}24.00 \\
24.34\end{array}$ & $\begin{array}{l}\text { Dense to very dense, medium brownish grey silty } \\
\text { fine SAND }\end{array}$ & 7 & 10 & 12 & 17 & $40 \stackrel{21}{\mathrm{~mm}}$ & & $190 \underline{50} \mathrm{~mm}$ & $56 \%$ \\
\hline 25.50 & $\begin{array}{l}\text { Pale to light grey moltled dark grey, moderately } \\
\text { fractured, slightly weathered, strong coarse grain } \\
\text { GRANITE }\end{array}$ & & CR & $=1.50 \mathrm{~m}$ & $R R=1.3$ & $\mathrm{~m} / 1.50 \mathrm{n}$ & $\mathrm{RQD}=$ & $40 \%$ & \\
\hline 27.00 & Ditto & & CR & $=1.50 \mathrm{~m}$ & $\mathrm{RR}=1.2$ & $\mathrm{~m} / 1.50 \mathrm{n}$ & $\mathrm{RQD}=$ & $73 \%$ & \\
\hline 28.50 & Ditto & & CR & $=1.50 \mathrm{~m}$ & $R R=1.3$ & $\mathrm{~m} / 1.50 \mathrm{n}$ & $\mathrm{RQD}=$ & $65 \%$ & \\
\hline $\begin{array}{l}30.00 \\
30.50\end{array}$ & $\begin{array}{l}\text { Pale to light grey moltled dark grey, moderately } \\
\text { fractured, slightly weathered, strong coarse grain } \\
\text { GRANITE }\end{array}$ & & CR & $=0.50 \mathrm{~m}$ & $\mathrm{RR}=0.4$ & $\mathrm{~m} / 0.50 \mathrm{n}$ & $\mathrm{RQD}=$ & $24 \%$ & \\
\hline
\end{tabular}

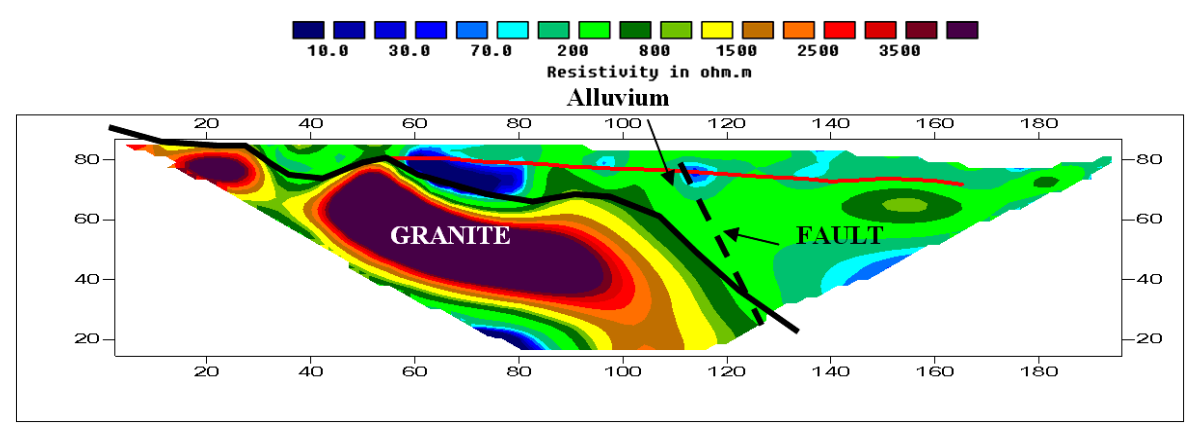

Figure 8. Resistivity pseudo-section of survey line SELA1. 


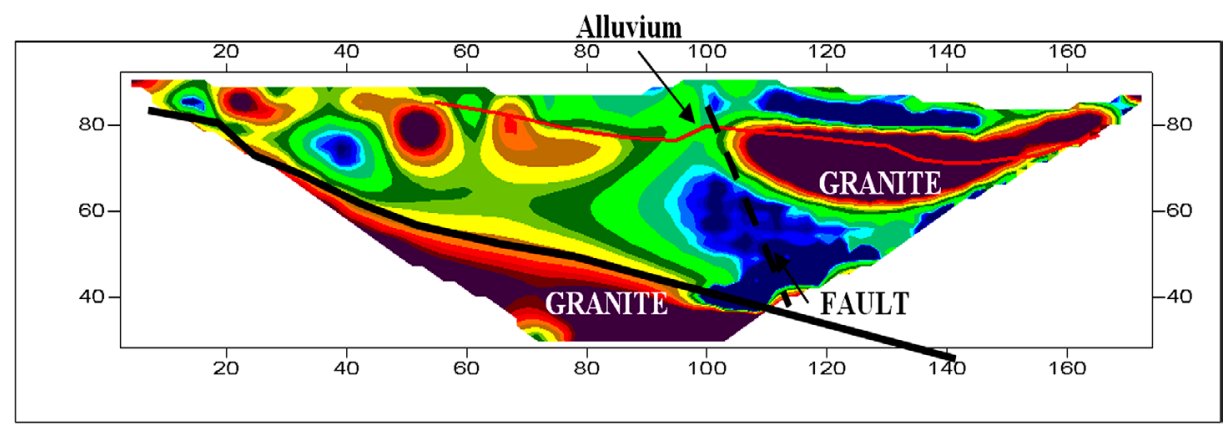

Figure 9. Resistivity pseudo-section of survey line SELA2.

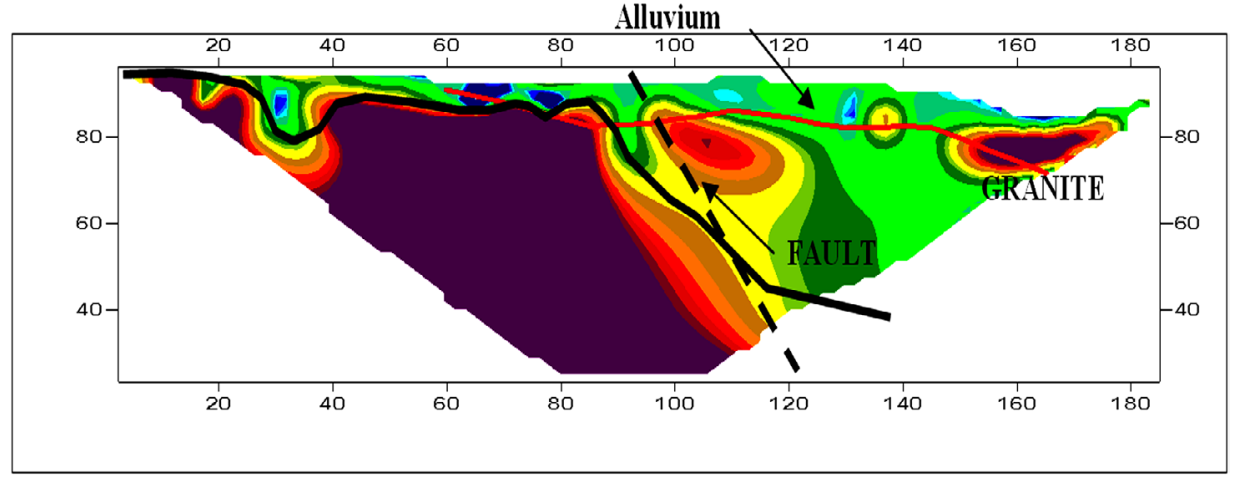

Figure 10. Resistivity pseudo-section of survey line SELA3.

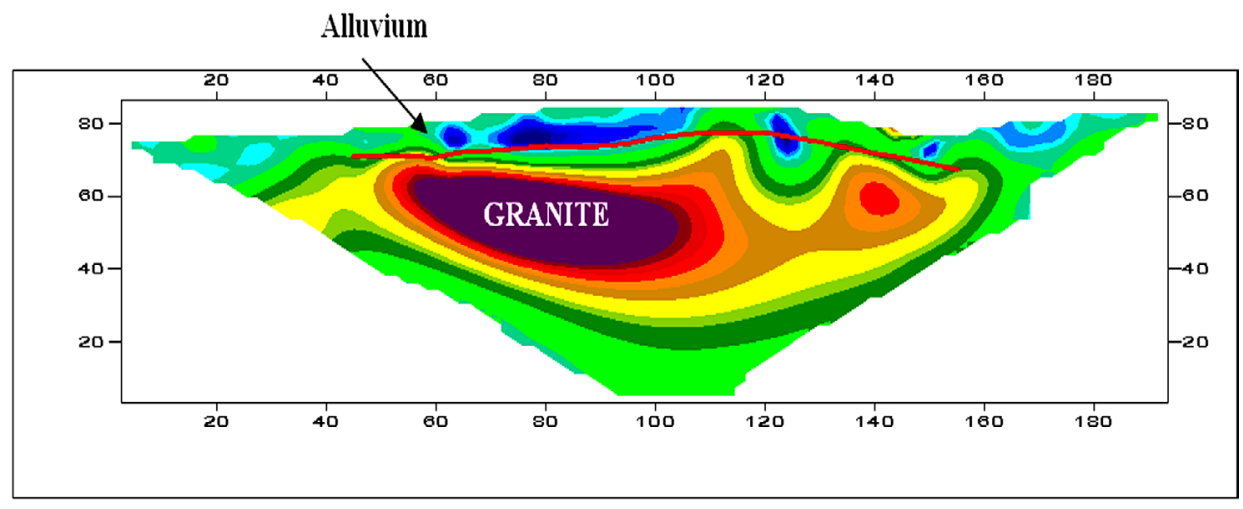

Figure 11. Resistivity pseudo-section of survey line SELA4.

\section{Conclusions}

2D resistivity method and seismic refraction results suggest that the study area consist of granite bedrock and alluvium mix with boulders. Hence, the geological contact outline is between granite and alluvium. There were faults along N-S at distance $100 \mathrm{~m}$ of SELA1-3.

\section{Acknowledgements}

The authors would like to extend sincere gratitude to all Geophysics Department Staff and Postgraduate students of School of Physics, Universiti Sains Malaysia for their assistance in acquiring the geophysical data and making the research a success.

\section{REFERENCES}

[1] R. C. Howe, “Geologic Contacts,” Journal of Geoscience Education, Vol. 45, 1997, pp. 133-136.

[2] G. H. Davis, "Structural Geology of Rocks and Regions," John Wiley \& Sons, Inc., 1984, p. 492.

[3] R. Saad, M. M. Nordiana and Edy Tonnizam Mohamad, "The 2D Electrical Resistivity Tomography (ERT) Study for Civil and Geotechnical Engineering Purposes,” Electronic Journal of Geotechnical Engineering, Bund, Vol. 16, 2011.

[4] F. W. Roe, "The Geology and Mineral Resources of The Neighbourhood of Kuala Selangor and Rasa, Selangor, Federation of Malaya, with an Account of The Geology of Batu Arang Coal-Field,” Geological Survey Depart- 
ment Federation of Malaya, 1953.

[5] R. Saad, "Novel Protocol of Engineering Geophysics In Urban Environments," Ph.D. Thesis, University Sains Malaysia, 2009.

[6] R. L. Sengbush, "Seismic Exploration Methods," IHRDC Publishers, 1983. doi:10.1007/978-94-011-6397-2

[7] D. H. Griffiths and R. F. King, “Applied Geophysics for Geologists and Engineers: The Elements of Geophysical J Prospecting,” Pergamon Press, 1981.
[8] J. M. Reynolds, “An Introduction to Applied and Environmental Geophysics,” John Wiley \& Sons, Ltd., 1997, p. 796.

[9] R. Barker, "Electrical Imaging and its Application in Engineering Investigations,” Engineering Geology Special Publications, Geological Society, London, Vol. 12, No. 1, 1997, pp. 37- 43.

[10] M. H. Loke, "Electrical Imaging Surveys for Environmental and Engineering Studies," A Practical Guide to 2-D and 3-D Surveys, 1999.www.abem.se 